Article

\title{
Assessment of Sustainability and Priorities for Development of Indian West Coast Region: An Application of Sustainable Livelihood Security Indicators
}

\author{
Viswanatha Reddy Krishna ${ }^{1,2, *}$, Venkatesh Paramesh ${ }^{2}\left(\mathbb{D}\right.$, Vadivel Arunachalam ${ }^{2}$, Bappa Das ${ }^{2} \mathbb{}$, \\ Hosam O. Elansary ${ }^{3,4, *} \mathbb{D}$, Arjun Parab ${ }^{2}$, Dendi Damodar Reddy ${ }^{1}$, K. S. Shashidhar ${ }^{5}{ }^{(0}$, \\ Diaa O. El-Ansary ${ }^{6}$, Eman A. Mahmoud ${ }^{7}$ and Mohamed A. El-Sheikh ${ }^{8}$ \\ 1 ICAR-Central Tobacco Research Institute, Rajahmundry, Andhra Pradesh-533105, India; \\ ddreddy132@gmail.com \\ 2 ICAR-Central Coastal Agricultural Research Institute, Old Goa, Goa 403402, India; \\ parameshagron@gmail.com (V.P.); v.arunachalam@icar.gov.in (V.A.); bappa.iari.1989@gmail.com (B.D.); \\ parabarjun72@gmail.com (A.P.) \\ 3 Plant Production Department, College of Food and Agricultural Sciences, King Saud University, \\ P.O. Box 2455, Riyadh 11451, Saudi Arabia \\ 4 Floriculture, Ornamental Horticulture, and Garden Design Department, Faculty of Agriculture (El-Shatby), \\ Alexandria University, Alexandria 21545, Egypt \\ 5 Department of Agronomy, Central Agricultural University, Imphal, Manipur 795004, India; \\ shashiuas@gmail.com \\ 6 Precision Agriculture Laboratory, Department of Pomology, Faculty of Agriculture (El-Shatby), \\ Alexandria University, Alexandria 21545, Egypt; diaaagri@hotmail.com \\ 7 Department of Food Industries, Damietta University, Damietta 34517, Egypt; emanmail2005@yahoo.com \\ 8 Botany \& Microbiology Department, College of Science, King Saud University, P.O. Box 2455, \\ Riyadh 11451, Saudi Arabia; melsheikh@ksu.edu.sa \\ * Correspondence: vishu.uas@gmail.com (V.R.K.); helansary@ksu.edu.sa (H.O.E.); \\ Tel.: +966-581216322 (H.O.E.)
}

Received: 20 August 2020; Accepted: 13 October 2020; Published: 21 October 2020

\begin{abstract}
The measurement of sustainability in terms of social, economic, and ecological indicators significantly influences the achievement of sustainable development goals. This paper presents a sustainable livelihood security index (SLSI) by selecting 20 indicators and positions them within the ecological, economic, and social dimensions of sustainable development for the Indian west coast. These indicators were first normalized and, using estimated weights, indices were computed. Important indicators were shortlisted by a two-step process, namely, principal component analysis and linear and nonlinear weighted scores. The results revealed that indicators such as forest cover, net sown area, milk availability, groundwater availability, land productivity, food grain availability, rural road connectivity, villages electrified, and land degradation were found to be important indicators. Kerala was found as the most developed state followed by Gujarat, Karnataka, Maharashtra, and Goa in linear and non-linear weighted scoring. The study identifies the Jamnagar, Junagadh, Kachchh, Ratnagiri, and Sindhudurg districts as the districts with the highest priority for development through investment and policy interventions. The study concludes that the west coast region, in terms of its sustainable development levels, improved significantly with a focus on low-SLSI districts by considering ecological, economic, and social dimensions in planning for technological development and dissemination.
\end{abstract}


Keywords: development; India; indicators; planning; policy; sustainable livelihood security index; west coast

\section{Introduction}

Improving the sustainability of a region is necessary to achieve sustainable development goals. Such development is essential particularly in the fragile ecosystem and biodiversity-rich region of coastal India. Sustainable development is defined as "development that meets the needs of the present without compromising the ability of future generations to meet their own needs" [1]. Sustainability of a particular region is influenced by several key factors comprising economic, environmental, and social indicators [2]. Analyzing the degree of sustainability with the application of a composite indicator called the sustainable livelihood security index (SLSI) is imperative. The SLSI is an index that encompasses multiple dimensions of overall development (ecological, economic, and social) of a region or ecosystem. Sustainability in a particular region is maintained by managing ecosystem, economic, and social factors [3]. The sustainable livelihood security index is an effective tool for the evaluation of sustainability as it is simple, informative, and easily understandable [4]. It is beneficial for drafting policies and plans for the upliftment of livelihood security of the local farmers with new income-generating strategies and enhancement of knowledge. It provides a one-dimensional metric to evaluate country-specific information on multi-dimensions of sustainable development such as economic, environmental, and social conditions [5]. The index is helpful to reorient development programs and prioritize development investments in highly vulnerable areas. Sustainable development is implicit as the effect of qualitative and quantitative transformation processes occurring in ecological, economic, and social spheres. In easy terms, it results from positive changes in the level of economic and social development, without any deterioration in the quality of the natural environment, focusing on its gradual improvement [6-9]. The deprived regions are provided with resources and opportunities to improve their ecological, economic, and social status [10]. Evaluation of sustainability at a large spatial scale is complex due to heterogeneity in ecology, climate, and socioeconomic conditions. So, the sustainability of regions dependent on agriculture should better be assessed at the regional level.

Earlier studies have demonstrated the suitability of SLSI as a holistic policy tool for assessment of agricultural sustainability at the regional level with different indicators [11-14]. Bhandari and Grant (2007) [15] analyzed the livelihood security in the Kali-Khola watershed region of Nepal and reported that agriculture production alone was not a viable livelihood option for the studied region. Hatai and Sen (2008) [16] studied agricultural sustainability in Orissa and revealed that the agricultural systems of all the districts display wide variations in their ecological, economic, and social equity aspects. Singh and Hiremath (2010) [17] reported the SLSI is a comprehensive index for measuring long-term livelihood security in the rural, as well as the urban, areas of Gujarat. Sajjad and Nasreen (2016) [3] assessed agricultural sustainability and revealed that agricultural sustainability among farmers decreased as the size of land holdings decreased. Nambiar et al. (2001) [18] measured agricultural sustainability using soil health, crop yield, and other indicators in coastal Bangladesh. Most of the indicators used in these studies focus on agricultural sustainability in the selected regions. District-level health data alone were used to measure sustainable development in Kenya [19].

The Indian west coast region in this study is a mega biodiversity region in the South Asian region with a total geographic area of 1600 square $\mathrm{km}$ spread over five states in 33 districts. A single district in the region Kutch is as large as 45.65 thousand square kilometers, which is greater than the size of the country of Denmark. The United Nations' Sustainable Development Goals (SDGs), namely, SDG-2 on hunger (food grain and milk availability), SDG-3 for good health (infant mortality), SDG-5 for good gender equality (\% female literacy), SDG-8 for decent work and economic development (labor productivity), SDG-13 for climate action (\% forest cover, groundwater stress, and area under land degradation), and SDG-15 on life on land (net sown area, human and 
livestock density), are important to be analyzed for the sustainability assessment of a region (DESA, Sustainable Development, United Nations, 2020) [20]. The concept of sustainable development is defined in several ways but is defined as "the long-term stability of both economy and environment" by Emas (2015) [21]. Sustainable development in Indonesia has been explored using different indicators [22]. The study indicated the improvement of social and economic factors while ignoring the environmental aspects in Indonesia. A sustainable development index as proposed by Hickel (2020) [23] is a ratio of a development index to an ecological impact index. The development index was derived from educational, life expectancy, and income index values whereas environmental impact index is calculated using material footprints and emission values. This demonstrates development versus environmental degradation.

This study employed a mix of 20 indicators initially, most of them chosen from agricultural sustainability and few of them addressing the SDGs of United Nations (zero hunger, good health and well-being, gender equity, climate action, and life on land) [20]. A few studies have attempted to include part of the Indian west coast using seven physical/geo-morphological and four socio-economic parameters in coastal Karnataka [24]. Though several frameworks and models have been proposed for measuring agricultural sustainability in the past, it is a complex concept and there is no consensus among researchers about its dimensions and indicators. The earlier delineation of these districts/regions were based on soil, climate, physiography, effective rainfall, and soil groups. However, these classifications are having certain limitations in policy planning and affecting development of these districts. To the best of our knowledge, a sustainability assessment in this region of India has not been conducted in recent years, based on economic, social, and ecological indicators. As these indicators will influence much in achieving sustainable development goals, the present research work was carried out with the objectives to (a) assess the sustainability of west coast India using linear and non-linear weighted approaches with three-dimensional indicators, which will help the researchers and policy makers, (b) analyze the spatial/regional variation in degree of sustainable development in the west coast region of India, and (c) identify the highly vulnerable regions/districts in terms of the SLSI in west coast India, which aids in drafting appropriate development policies and programs for the improvement of the west coast region.

\section{Materials and Methods}

\subsection{Study Area}

In the study, we selected 33 coastal districts of west coast India, which accounts for more than $95 \%$ of the geographical area in the west coast region of India in five different coastal states: Goa, Kerala, Karnataka, Maharashtra, and Gujrat. The western coastal region is a strip of coastal plain $50 \mathrm{~km}$ in width between the west coast of India and the Western Ghats hills, which starts near the south of the Tapti River. This region is located between the Western Ghats and the Arabian Sea and has rich biodiversity and tremendous potential for agricultural development.

The selection of indicators is of extreme importance for any study on the assessment of sustainable development. Hence, much care has been taken to finalize the variables under each indicator by a thorough review of published literature and discussion with experts to determine the functional relationships.

Principal component analysis (PCA) was used in the current study with two-fold objectives.

1. For calculation of the weights: In most of the earlier studies on the SLSI, the weights were calculated based on expert opinion, which is highly subjective. In this study, we have used an objective based weighting of the indicator variables, i.e., based on PCA.

2. To reduce the data dimensionality: The variables collected under each category of ecological security, economic efficiency, and social equity may be correlated with each other, a phenomenon called multi-collinearity. When the correlation between any two variables is more than 0.75 , they contain the same information and any one of them can be used for further analysis. Therefore, 
in the current study, PCA was used to reduce the dimensionality of data while retaining the lion's share of the variability present in the original data.

Furthermore, a minimal set of indicators were chosen in this study using principal component analysis and linear and non-linear score functions were used to work out a weighted indicator to measure sustainability. Each indicator may not contribute equally to the target measurement of sustainability. The contribution of an indicator may be positive or negative. Hence, each of the indicators was normalized to be measured on a common scale. A non-linear weighted scoring was used to combine the indicators with a weight based on their relative importance to get a clear picture of the situation. A weighted score index is used in many studies to assign relative importance to the indicators $[25,26]$.

The data collected on parameters pertaining to ecological, economic, and social indicators for computation of the SLSI for the west coast of India are described in brief in Table 1. For an empirical estimation of the SLSI, a novel approach was followed involving the selection of a set of variables using principal component analysis (PCA), providing more relevant information about the ecological, economic, and social dimensions of sustainable agricultural development.

Table 1. The indicators of sustainable development selected for analysis for the sustainable livelihood security index (SLSI).

\begin{tabular}{|c|c|c|c|c|}
\hline & Indicator & $\begin{array}{l}\text { Importance of an Indicator for } \\
\text { Sustainable Development }\end{array}$ & $\begin{array}{c}\text { Functional } \\
\text { Relationship }\end{array}$ & Data Source \\
\hline \multicolumn{5}{|c|}{ Ecological Security Indicators } \\
\hline 3 & $\begin{array}{l}\text { Livestock density } \\
\text { index (number of } \\
\text { livestock per km²) }\end{array}$ & $\begin{array}{l}\text { These two indicators (human density and } \\
\text { livestock density) are significant as they } \\
\text { reflect the extent of pressure on the natural } \\
\text { ecosystem in terms of agriculture, animal } \\
\text { husbandry, and other economic activities } \\
\text { and habitat degradation }\end{array}$ & Negative & $\begin{array}{c}\text { Government of India, } \\
\text { Directorate of Economics } \\
\text { and Statistics (Livestock } \\
\text { Census, 2012) [29] }\end{array}$ \\
\hline 5 & $\begin{array}{l}\text { Variation in rainfall } \\
\text { (coefficient of } \\
\text { variation) }\end{array}$ & $\begin{array}{c}\text { This indicator captures rainfall fluctuations } \\
\text { across the different districts. Some states } \\
\text { have largest area under rain-fed agriculture } \\
\text { and some states have high rainfall. A stable } \\
\text { rainfall is a very robust ecological indicator } \\
\text { in the state }\end{array}$ & Negative & $\begin{array}{c}\text { India Meteorological } \\
\text { Department website, } \\
2016[31]\end{array}$ \\
\hline 6 & $\begin{array}{l}\text { Groundwater } \\
\text { development stress } \\
\text { (\% annual draft } \\
\text { over the annual } \\
\text { recharge) }\end{array}$ & $\begin{array}{l}\text { It indicates that groundwater is available } \\
\text { for future use. Recharge potential of } \\
\text { groundwater serves not only as an } \\
\text { indicator of ecological security but also as } \\
\text { an indicator of intergenerational equity }\end{array}$ & Negative & $\begin{array}{l}\text { CGWB, MoWR } \\
\text { (2011) [32] }\end{array}$ \\
\hline
\end{tabular}


Table 1. Cont.

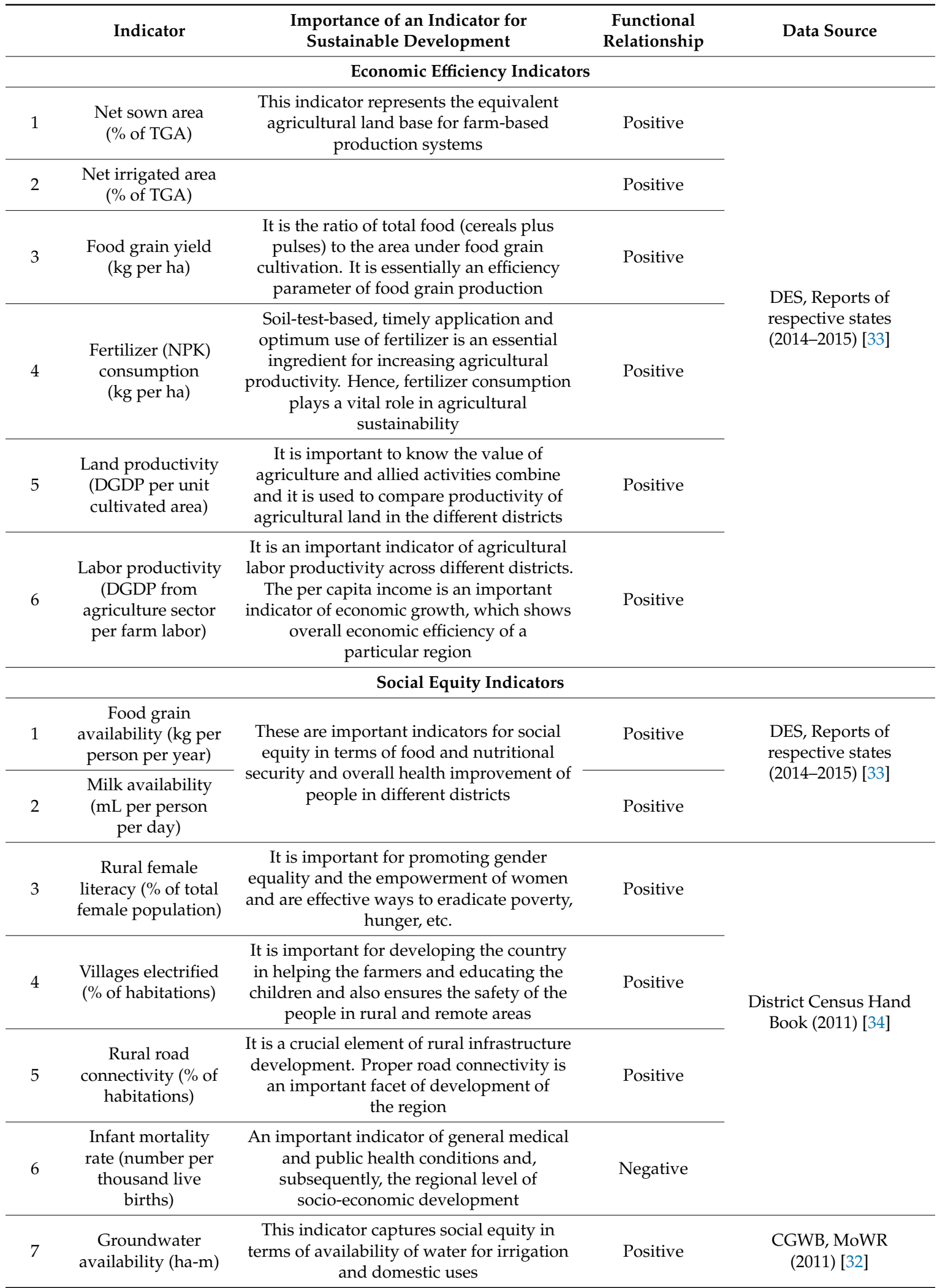

Notes: DGDP, district gross domestic product at constant price 2004-2005. TGA, GCA, NSA, GoI, MoWR, DES, and CGWB stand for total geographical area, gross cropped area, net sown area, Government of India, Ministry of Water Resources, Directorate of Economics and Statistics, and Central Groundwater Board, respectively. 


\subsection{Principal Component Analysis (PCA) and Indicator Scoring}

The total dataset was used for principal component analysis (PCA) to minimize the dimensionality of indicators and select the most significant ones. The number of principal components (PCs) were selected by considering eigenvalues and their individual percentage of variability. Following Brejda et al. (2000) [35] in the current investigation, the PCs with eigenvalues $\geq 1$ and that accounted for more than $5 \%$ of the variation in the data were considered. In each PC, the indicators with higher factor loading (with absolute values less than $20 \%$ of the highest factor loading) were considered as the best representative of the system traits and hence selected for the minimum data set (MDS). Each indicator of the MDS was normalized and considered for the SLSI calculation. The normalized value of each indicator, termed the "indicator score" (S), was computed by linear and nonlinear scoring techniques.

\subsection{Linear and Non-Linear Scoring Technique}

Depending on whether the higher value was determined "harmful" or "useful" in the SLSI, indicators were designated as "less is better" or "more is better", respectively. The linear and non-linear transformations were computed using the following formulae (Equations (1)-(3)).

$$
\begin{gathered}
Y_{L M}=\frac{\left(X_{i}-X_{\min }\right)}{\left(X_{\max }-X_{\min }\right)} \\
Y_{L L}=\frac{\left(X_{\max }-X_{i}\right)}{\left(X_{\max }-X_{\min }\right)} \\
Y_{N L}=\frac{\mathrm{a}}{\left(1+\left(X_{i} / X_{\text {mean }}\right)\right)^{\mathrm{b}}}
\end{gathered}
$$

where $X_{\text {mean }}, X_{\max }$, and $X_{\min }$ are the mean, maximum, and minimum values of each indicator under consideration, respectively. $X_{i}$ is the SLSI indicator value. a reflects the maximum value reached by the function; in our case, the nonlinear function reaches the maximum value when $\mathrm{a}=1 \mathrm{.} \mathrm{b}$ is the slope of the equation. The value of $b$ was identified to be equal to -10.5 and +10.5 for "more is better" and "less is better", respectively by a sigmoidal fit. $Y_{L M}$ and $Y_{L L}$ are the linear scores for the "more is better" and "less is better" functions, respectively. $Y_{L N}$ is the non-linear score function. An amalgamation of both "more is better" and "less is better" functions were used for an "optimum" scoring function. Indicators such as forest cover, cropping intensity, net sown area, food grain yield, milk availability, net irrigated area, fertilizer consumption, food grain availability, rural female literacy, groundwater availability, rural road connectivity, villages electrified, land productivity, and labor productivity were considered "more is better". Remaining indicators such as human density; livestock density; coefficient of variation of annual rainfall; groundwater stress; land degradation; and infant mortality rate were considered "less is better".

\subsection{Sustainable Livelihood Security Index (SLSI)}

Indicators were amalgamated into the SLSI by weighted SLSIs (WSLSIs). Higher index values were considered to signify better sustainability. The weight of each MDS variable was calculated by the ratio of variation explained by that PC to the cumulative variance explained by the PCs with eigenvectors $\geq 1.0$.

The WSLSI was calculated by means (Equation (4)).

$$
W S L S I=\sum_{i=1}^{n}\left(W_{i} \times S_{i}\right)
$$

where $W_{i}$ is the PC weighting factor and $S_{i}$ is the indicator score of the variable $i$. In the model, greater index scores depict good crop status. 


\section{Results}

\subsection{Sustainable Livelihood Security Indicators}

The mean data of coastal districts of five west coast Indian states for 20 SLSI indicators, namely, ecological (human density, livestock density, forest cover, rainfall variation, groundwater stress, cropping intensity, and land degradation), economical (net sown area, net irrigated area, food grain yield, fertilizer consumption, land productivity, and labor productivity), social (food grain availability, milk availability, rural female literacy, villages electrified, rural road connectivity, infant mortality rate, and groundwater availability) indicators, are presented in Table 2.

\subsection{Selection of Minimum Data Set (MDS)}

The eigenvalues, percentage variability, and cumulative variance of each PC are given in Table 3. The amount of variability accounted for by PCA in terms of PC1, PC2, PC3, PC4, and PC5 was 31.906\%, $15.83 \%, 10.881 \%, 8.165 \%$, and $8.129 \%$, respectively (Table 3). Nevertheless, the cumulative variance through PC5 was 74.911\%. Within each PC, only highly weighted factors (having absolute values more than 0.8 irrespective of the sign of the factor loading) were retained for the MDS. In PC1, five variables were found to be best based on factor loadings, i.e., forest cover, net sown area, milk availability, groundwater availability, and land productivity as PC1 contributed maximum variability (31.906\%). In PC2, food grain availability; in PC3, rural road connectivity and villages electrified; in PC4, infant mortality rate; and in PC5, land degradation were found to be the best indicators.

Table 2. The average data of coastal districts of respective states on ecological, economic efficiency and social equity indicators.

\begin{tabular}{|c|c|c|c|c|c|}
\hline Variables (Unit) & Kerala & Karnataka & Goa & Maharashtra & Gujarat \\
\hline Human density (persons $\mathrm{km}^{-2}$ ) & 1105 & 300 & 399 & 465 & 459 \\
\hline Livestock density (livestock $\mathrm{km}^{-2}$ ) & 285 & 968 & 478 & 576 & 1964 \\
\hline Forest cover $(\%)$ & 35 & 54 & 60 & 40 & 9 \\
\hline CV rainfall $(\%)$ & 14 & 18 & 19 & 21 & 29 \\
\hline Cropping intensity (\%) & 125 & 119 & 101 & 106 & 110 \\
\hline Net irrigated area $(\%)$ & 19 & 37 & 26 & 6 & 45 \\
\hline Land degradation (000 ha) & 252 & 625 & 538 & 757 & 987 \\
\hline Groundwater stress (\%) & 43 & 30 & 31 & 30 & 57 \\
\hline Net sown area (000 ha) & 1616 & 1132 & 685 & 2045 & 4203 \\
\hline Food grain yield $\left(\mathrm{kg} \mathrm{ha}^{-1}\right)$ & 2654 & 2347 & 3825 & 2111 & 2274 \\
\hline Milk availability $\left(\mathrm{mL}\right.$ person ${ }^{-1}$ day $^{-1}$ ) & 152 & 132 & 68 & 3 & 337 \\
\hline Fertilizer consumption $\left(\mathrm{kg} \mathrm{ha}^{-1}\right)$ & 407 & 946 & 53 & 515 & 27 \\
\hline Food grain availability $\left(\mathrm{kg}\right.$ person $\left.{ }^{-1} \mathrm{yr}^{-1}\right)$ & 300 & 180 & 115 & 283 & 235 \\
\hline Rural female literacy $(\%)$ & 59 & 78 & 45 & 28 & 23 \\
\hline $\begin{array}{l}\text { Infant mortality rate (number thousand } \\
\text { live births }{ }^{-1} \text { ) }\end{array}$ & 7 & 14 & 9 & 15 & 9 \\
\hline Groundwater availability (ha-m) & 45,635 & 39,361 & 7272 & 47,366 & 76,533 \\
\hline Rural road connectivity (\%) & 100 & 94 & 96 & 95 & 95 \\
\hline Villages electrified (\%) & 100 & 100 & 100 & 100 & 100 \\
\hline Land productivity (DGDP cultivated area $^{-1}$ ) & 0.3 & 0.3 & 0.1 & 0.2 & 0.4 \\
\hline $\begin{array}{l}\text { Labor productivity (DGDP from agriculture } \\
\text { sector agriculture labor }{ }^{-1} \text { ) }\end{array}$ & 0.4 & 0.3 & 0.1 & 0.2 & 0.6 \\
\hline
\end{tabular}


Table 3. Performance of ecological, economic, and social indicators in terms of factor loading/eigenvector values in principal component (pc) analysis.

\begin{tabular}{cccccc}
\hline Components & PC1 & PC2 & PC3 & PC4 & PC5 \\
\hline Eigenvalue & 6.38 & 3.16 & 2.17 & 1.63 & 1.62 \\
\% of variance & 31.90 & 15.8 & 10.88 & 8.16 & 8.12 \\
Cumulative $\%$ & 31.90 & 47.73 & 58.61 & 66.78 & 74.91 \\
\hline \multicolumn{7}{c}{ Factor Loading/Eigenvectors } & & \\
\hline Human density & -0.10 & 0.69 & 0.33 & 0.42 & 0.13 \\
Livestock density & 0.60 & -0.37 & -0.12 & -0.34 & -0.08 \\
Forest cover & -0.8 & 0.01 & -0.09 & 0.02 & 0.12 \\
CV Rainfall & 0.74 & -0.56 & -0.21 & -0.05 & 0.05 \\
Groundwater stress & 0.71 & -0.10 & 0.10 & 0.09 & -0.04 \\
Cropping intensity & -0.11 & 0.75 & -0.05 & -0.04 & 0.15 \\
Land degradation & 0.02 & -0.06 & 0.08 & 0.12 & -0.85 \\
Net sown area & 0.88 & -0.29 & -0.01 & 0.05 & -0.034 \\
Food grain yield & 0.13 & 0.45 & 0.24 & -0.43 & 0.3 \\
Milk availability & 0.86 & -0.11 & -0.01 & -0.13 & 0.33 \\
Net irrigated area & 0.78 & -0.25 & -0.03 & 0.19 & 0.18 \\
Fertilizer consumption & -0.34 & 0.52 & 0.06 & 0.09 & -0.41 \\
Food grain availability & -0.10 & 0.82 & 0.20 & -0.15 & -0.08 \\
Rural female literacy & -0.60 & 0.40 & 0.22 & 0.13 & 0.36 \\
Infant mortality rate & -0.02 & -0.05 & -0.02 & 0.86 & -0.15 \\
Groundwater availability & 0.83 & 0.08 & -0.21 & -0.09 & 0.13 \\
Rural road connectivity & -0.10 & 0.29 & 0.90 & -0.03 & 0.01 \\
Villages electrified & 0.15 & 0.05 & 0.94 & -0.04 & -0.11 \\
Land productivity & 0.47 & 0.19 & -0.19 & 0.51 & 0.43 \\
Labor productivity & 0.83 & 0.09 & 0.22 & -0.01 & 0.05 \\
\hline
\end{tabular}

\subsection{Indicator Transformation (Scoring)}

The results of the linear scoring method were determined by the variance of each indicator as each observation is relative to the lowest (or highest) observation for "minimum (or maximum) is better" indicators. Likewise, when the more (or less) score is an outlier, proper understanding of the dataset is necessary to identify that it should be thrown out; otherwise all the subsequent scores might be unreasonably skewed. With regard to the linear weighted scoring and nonlinear weighted scoring (Figure 1), Kerala is securing top position followed by Gujarat, Karnataka, Maharashtra, and Goa.

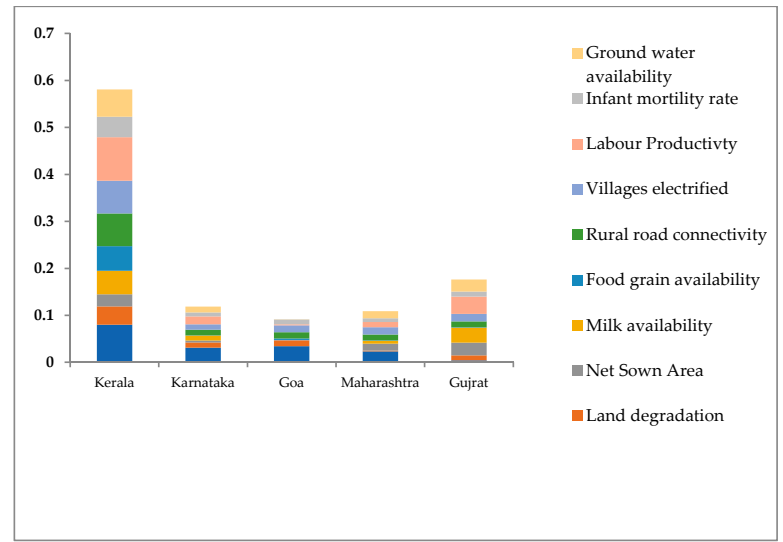

B-Linear Scoring Weighted CSSI

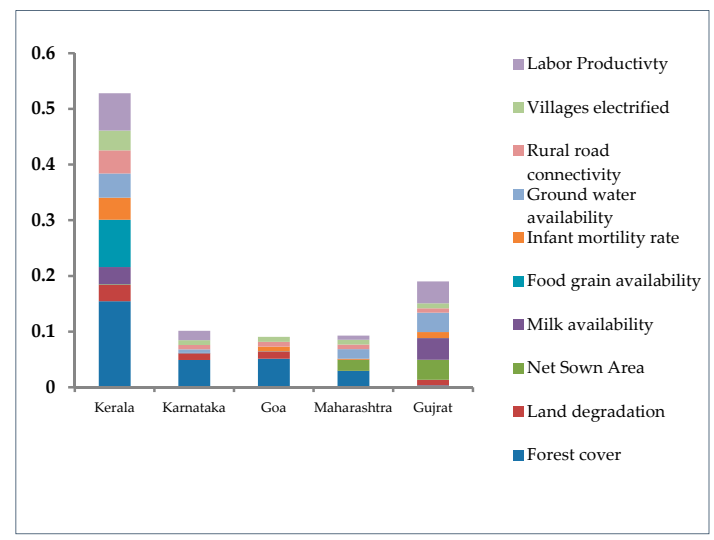

D-Nonlinear Scoring Weighted CSSI

Figure 1. B- and D-weighted SLSI indicators using linear or non-linear scored indicators chosen by principal component analysis minimum data set (MDS) selection technique for different SLSI indicators. 
The linear weighted score depicted (Figure 2A) that among all states, Kerala is well developed for most of the indicators except land degradation and the net sown area. All other states recorded much lower scores than the Kerala state. In Karnataka, only forest cover and labor productivity have scored the maximum, while the rest of the indicators are on par with other states. In Goa, only forest cover is leading compared to other parameters. In Maharashtra, forest cover and villages electrified became important indicators influencing sustainability followed by groundwater availability.

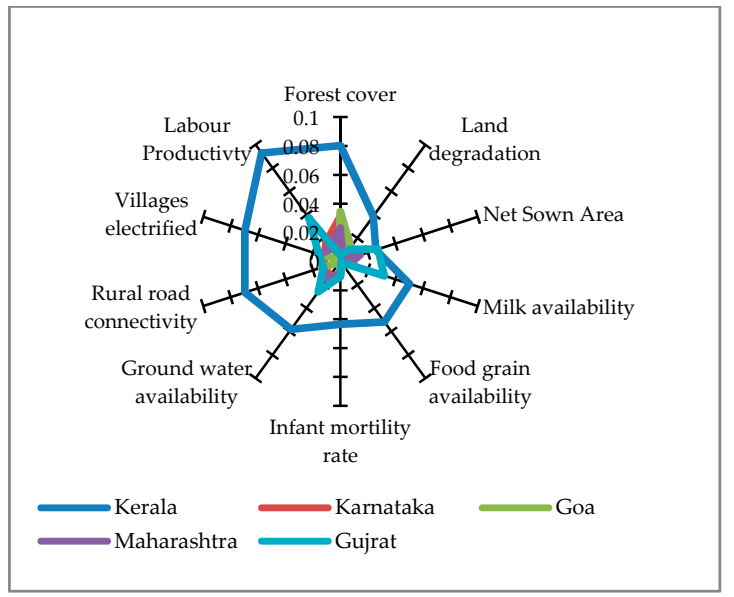

(A)

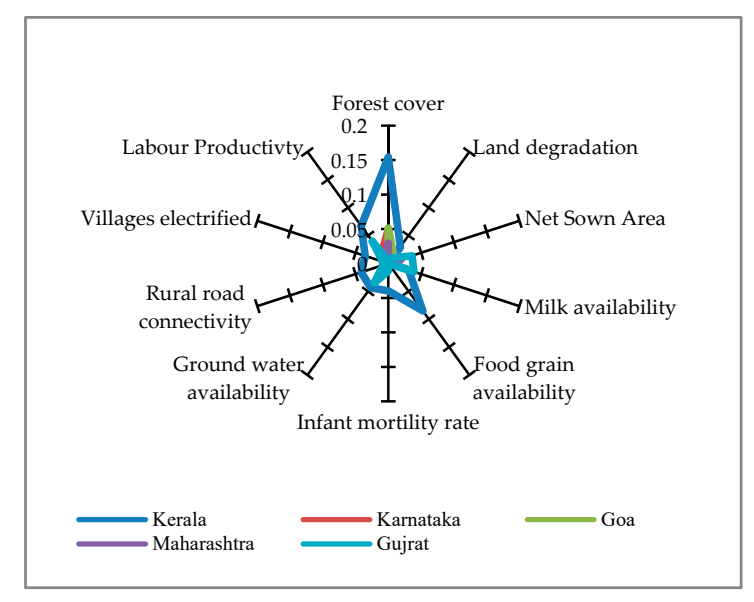

(B)

Figure 2. A and B-radar plot of weighted CSI under various SLSI indicators. (A) Linear weighted, (B) non-linear weighted.

In Gujarat, labor productivity, milk availability, groundwater availability, and net sown area are leading among the other parameters. The non-linear weighted score presented in Figure 2B reveals that Kerala is the leading state for all indicators except net sown area. In the case of Karnataka, forest cover and labor productivity have scored the maximum as compared to other factors. Similarly, in Goa, forest cover and land degradation have secured the maximum score as compared to the other parameters. In Maharashtra, forest cover, net sown area, and groundwater availability are leading in the score compared to others. In the case of Gujarat, net sown area, milk availability, available groundwater, and labor productivity secured the maximum score over the rest of the others.

\subsection{Ranking of Ecological Security Index, Economic Efficiency Index, and Social Equity Index}

State-wise ranking of the Ecological Security Index (ESI), Economic Efficiency Index (EEI), and Social Equity Index (SEI) is highlighted in Table 4. The state Karnataka has achieved higher ESI (0.73), followed by Goa (0.68) and Kerala (0.64), than other states, whereas the EEI was found highest in Gujarat State (0.46) and the lowest value is observed in Goa state (0.14). The highest SEI is observed in the Kerala state followed by the Gujarat state (0.55). Furthermore, the district-wise ranking of the ESI, EEI, and SEI indicated that, among different coastal districts, the Uttar Kannada district of Karnataka achieved the highest ESI (0.81). Similarly, the highest EEI (0.75) and SEI (0.75) scores were observed in Rajkot of Gujarat state and Thrissur of Kerala state, respectively (Table 5).

Table 4. State-wise ranking of the Ecological Security Index (ESI), Economic Efficiency Index (EEI), and Social Equity Index (SEI).

\begin{tabular}{ccccccc}
\hline States & ESI & ESI Rank & EEI & EEI Rank & SEI & SEI Rank \\
\hline Kerala & 0.64 & 3 & 0.34 & 2 & 0.66 & 1 \\
Karnataka & 0.73 & 1 & 0.30 & 4 & 0.49 & 3 \\
Goa & 0.68 & 2 & 0.14 & 5 & 0.44 & 4 \\
Maharashtra & 0.49 & 4 & 0.3 & 3 & 0.44 & 5 \\
Gujarat & 0.44 & 5 & 0.46 & 1 & 0.55 & 2 \\
\hline
\end{tabular}


Table 5. District-wise ranking of the ESI, EEI, and SEI.

\begin{tabular}{|c|c|c|c|c|c|c|}
\hline Districts & ESI & Rank & EEI & Rank & SEI & Rank \\
\hline Alappuzha & 0.61 & 11 & 0.31 & 20 & 0.72 & 3 \\
\hline Ernakulum & 0.66 & 7 & 0.47 & 9 & 0.73 & 2 \\
\hline Kannur & 0.70 & 4 & 0.32 & 18 & 0.58 & 13 \\
\hline Kasaragod & 0.53 & 21 & 0.37 & 15 & 0.54 & 19 \\
\hline Kollam & 0.67 & 6 & 0.26 & 26 & 0.70 & 4 \\
\hline Kottayam & 0.72 & 3 & 0.34 & 17 & 0.65 & 9 \\
\hline Kozhikode & 0.63 & 10 & 0.31 & 19 & 0.56 & 16 \\
\hline Malappuram & 0.60 & 13 & 0.26 & 24 & 0.66 & 7 \\
\hline Thrissur & 0.57 & 16 & 0.38 & 14 & 0.75 & 1 \\
\hline Thiruvananthapuram & 0.61 & 12 & 0.31 & 21 & 0.62 & 11 \\
\hline Dakshina Kannada & 0.60 & 14 & 0.41 & 12 & 0.57 & 15 \\
\hline Udupi & 0.76 & 2 & 0.19 & 29 & 0.59 & 12 \\
\hline Uttar Kannada & 0.81 & 1 & 0.28 & 22 & 0.30 & 33 \\
\hline North goa & 0.66 & 8 & 0.15 & 32 & 0.40 & 29 \\
\hline South goa & 0.69 & 5 & 0.11 & 33 & 0.46 & 27 \\
\hline Raigad & 0.52 & 22 & 0.20 & 27 & 0.40 & 30 \\
\hline Ratnagiri & 0.56 & 17 & 0.16 & 31 & 0.48 & 24 \\
\hline Sindhudurg & 0.64 & 9 & 0.18 & 30 & 0.47 & 26 \\
\hline Thane & 0.39 & 29 & 0.36 & 16 & 0.35 & 31 \\
\hline Ahmedabad & 0.30 & 32 & 0.57 & 3 & 0.47 & 25 \\
\hline Anand & 0.56 & 18 & 0.44 & 10 & 0.51 & 20 \\
\hline Amreli & 0.35 & 30 & 0.53 & 6 & 0.66 & 6 \\
\hline Bhavnagar & 0.46 & 24 & 0.55 & 4 & 0.66 & 8 \\
\hline Bharuch & 0.50 & 23 & 0.28 & 23 & 0.48 & 23 \\
\hline Jamnagar & 0.35 & 31 & 0.52 & 7 & 0.51 & 22 \\
\hline Junagadh & 0.42 & 26 & 0.53 & 5 & 0.63 & 10 \\
\hline Kachchh & 0.18 & 33 & 0.50 & 8 & 0.56 & 17 \\
\hline Navsari & 0.54 & 19 & 0.41 & 11 & 0.56 & 18 \\
\hline Porbandar & 0.40 & 28 & 0.26 & 25 & 0.31 & 32 \\
\hline Rajkot & 0.40 & 27 & 0.75 & 1 & 0.69 & 5 \\
\hline Surat & 0.44 & 25 & 0.62 & 2 & 0.57 & 14 \\
\hline Vadodara & 0.53 & 20 & 0.39 & 13 & 0.51 & 21 \\
\hline Valsad & 0.59 & 15 & 0.19 & 28 & 0.45 & 28 \\
\hline
\end{tabular}

\subsection{Sustainable Livelihood Security Index (SLSI)}

Computation of the sustainable livelihood security index based on linear weighted scoring and non-linear weighted scoring has clearly indicated that Kerala state is more sustainable compared to other studied coastal states in the west coast of India (Table 6). Among different coastal districts, Ernakulum and Alappuzha recorded higher SLSI values in linear and non-linear weighted scoring methods, respectively. The lowest SLSI values were observed in Kachchh district of Gujarat in both the methods followed by Ratnagiri district of Maharashtra. All the coastal districts of Kerala and Karnataka were found sustainable with higher SLSI values. All the coastal districts were found to be more sustainable with the values ranging from 0.84 to 1.00 in the linear weighted method and 0.65 to 1.00 in the non-linear weighted method in the case of Kerala and 0.70 to 0.81 in the linear weighted method and 0.68 to 0.83 in the non-linear weighted method in case of Karnataka. However, the values of the SLSI have shown huge variation in the Gujarat state; it varied between $0.35-0.94$ in the linear weighted method and $0.21-0.80$ in the non-linear weighted method. The highest SLSI values were observed in Navsari and Rajkot districts in linear and non-linear weighted scoring methods, respectively. The districts along with their SLSI values are given as Table 7 for prioritization of policy interventions by respective state-level agencies. 
Table 6. District- and state-wise sustainable livelihood security index (SLSI).

\begin{tabular}{|c|c|c|c|c|}
\hline Districts & $\begin{array}{l}\text { Linear Weighted } \\
\text { Scoring }\end{array}$ & $\begin{array}{c}\text { State } \\
\text { Average }\end{array}$ & $\begin{array}{c}\text { Non-Linear } \\
\text { Weighted Scoring }\end{array}$ & $\begin{array}{c}\text { State } \\
\text { Average }\end{array}$ \\
\hline Alappuzha & 0.93 & \multirow{10}{*}{0.91} & 1.00 & \multirow{10}{*}{0.85} \\
\hline Ernakulum & 1.00 & & 0.96 & \\
\hline Kannur & 0.95 & & 0.76 & \\
\hline Kasaragod & 0.87 & & 0.72 & \\
\hline Kollam & 0.88 & & 0.87 & \\
\hline Kottayam & 0.90 & & 0.85 & \\
\hline Kozhikode & 0.94 & & 0.97 & \\
\hline Malappuram & 0.84 & & 0.65 & \\
\hline Thrissur & 0.85 & & 0.84 & \\
\hline Thiruvananthapuram & 0.91 & & 0.92 & \\
\hline Dakshina Kannada & 0.80 & \multirow{3}{*}{0.77} & 0.76 & \multirow{3}{*}{0.76} \\
\hline Udupi & 0.81 & & 0.68 & \\
\hline Uttar Kannada & 0.70 & & 0.83 & \\
\hline North Goa & 0.71 & \multirow{2}{*}{0.69} & 0.63 & \multirow{2}{*}{0.60} \\
\hline South Goa & 0.66 & & 0.58 & \\
\hline Raigad & 0.54 & \multirow{4}{*}{0.58} & 0.51 & \multirow{4}{*}{0.53} \\
\hline Ratnagiri & 0.52 & & 0.39 & \\
\hline Sindhudurg & 0.58 & & 0.45 & \\
\hline Thane & 0.67 & & 0.77 & \\
\hline Ahmedabad & 0.81 & \multirow{14}{*}{0.70} & 0.66 & \multirow{14}{*}{0.58} \\
\hline Anand & 0.85 & & 0.69 & \\
\hline Amreli & 0.66 & & 0.56 & \\
\hline Bhavnagar & 0.76 & & 0.66 & \\
\hline Bharuch & 0.67 & & 0.57 & \\
\hline Jamnagar & 0.61 & & 0.50 & \\
\hline Junagadh & 0.63 & & 0.47 & \\
\hline Kachchh & 0.35 & & 0.21 & \\
\hline Navsari & 0.94 & & 0.71 & \\
\hline Porbandar & 0.55 & & 0.42 & \\
\hline Rajkot & 0.86 & & 0.80 & \\
\hline Surat & 0.83 & & 0.71 & \\
\hline Vadodara & 0.64 & & 0.57 & \\
\hline Valsad & 0.68 & & 0.58 & \\
\hline
\end{tabular}

Table 7. West coast districts in different classes of the SLSI.

\begin{tabular}{|c|c|c|}
\hline Classes & Linear Weighted Method & Non-Linear Weighted Method \\
\hline $\begin{array}{l}\text { Less Developed Districts } \\
\qquad(<0.5)\end{array}$ & Kachchh & $\begin{array}{l}\text { Ratnagiri } \\
\text { Sindhudurg } \\
\text { Jamnagar } \\
\text { Junagadh } \\
\text { Kachchh }\end{array}$ \\
\hline $\begin{array}{l}\text { Moderately Sustainable } \\
\text { Districts }(0.51-0.75)\end{array}$ & $\begin{array}{l}\text { Uttar Kannada } \\
\text { North Goa } \\
\text { South Goa } \\
\text { Raigad } \\
\text { Ratnagiri } \\
\text { Sindhudurg } \\
\text { Thane } \\
\text { Amreli } \\
\text { Bharuch } \\
\text { Jamnagar } \\
\text { Junagadh } \\
\text { Porbandar } \\
\text { Vadodara } \\
\text { Valsad }\end{array}$ & $\begin{array}{c}\text { Kasaragod } \\
\text { Malappuram } \\
\text { Udupi } \\
\text { North Goa } \\
\text { South Goa } \\
\text { Raigad } \\
\text { Ahmedabad } \\
\text { Anand } \\
\text { Amreli } \\
\text { Bhavnagar } \\
\text { Bharuch } \\
\text { Navsari } \\
\text { Surat } \\
\text { Vadodara } \\
\text { Valsad }\end{array}$ \\
\hline
\end{tabular}


Table 7. Cont.

\begin{tabular}{ccc}
\hline Classes & Linear Weighted Method & Non-Linear Weighted Method \\
\hline & Alappuzha & \\
Ernakulum & Kannur & \\
Kasaragod & Alappuzha \\
Kollam & Ernakulum \\
Kottayam & Kannur \\
Kozhikode & Kollam \\
Malappuram & Kottayam \\
Thrissur & Kozhikode \\
Dighly Sustainable & Thrissur \\
& Thiruvananthapuram $(>0.75)$ & Thiruvananthapuram \\
& Dakshina Kannada & Dakshina Kannada \\
& Udupi Ahmedabad & Uttar Kannada \\
Anand & Thane \\
& Bhavnagar & Rajkot \\
Navsari & \\
Rajkot & \\
& Surat &
\end{tabular}

Furthermore, the various districts of west coast India are classified into less, moderate, and highly sustainable districts to prioritize development activities to improve the sustainable development of the region. Among various west coast districts, only Kachchh was in the less sustainable category in the linear weighted method, however, in the non-linear weighted method, Ratnagiri, Sindhudurg, Jamnagar, Junagadh, and Kachch were found less sustainable. In the linear weighted method, about 14 and 18 districts were found moderately and highly sustainable, respectively. While in the non-linear weighted method, about 15 and 13 districts were found moderately and highly sustainable, respectively.

\section{Discussion}

\subsection{Ecological Security Index}

In the present study, ecological security was assessed in terms of human density, livestock density, forest cover, rainfall variation, groundwater stress, cropping intensity, and land degradation (Table 2). The data indicated that human density is maximum in Kerala (1105) while it is minimum in coastal Karnataka (300). In the huge area of west coast India, human density cannot be uniform; it depends on the biophysical environment and socio-economic conditions of the region. With respect to livestock density, Gujarat (1964) is leading among the west coast states of India. Livestock, directly and indirectly, provides employment, income, and nutritional security to rural and urban populations. Livestock plays a critical role in the enhancement of soil quality through providing valuable organic manure. The dairy-based sustainable livelihood security index studies in West Bengal [36] also indicate the role of livestock in sustainable livelihood development. Kerala, Gujarat, and Goa are found to be among the dairy-progressive states [37] of India. Similarly, livestock can improve soil fertility but also accelerate soil degradation depending on their density, damage the soil conditions, decrease residence time, and affect other management variables. The presence of livestock does not always result in land improvements.

Forest cover seems to be prominent in the Goa (59.55\%) while it is least available in Gujarat $(8.54 \%)$. Forest plays a major role in sustaining livelihoods through its several economic and ecological functions such as food and water availability and biodiversity conservation. Forest cover is also important for watershed management, carbon sequestration, and air purification [38]. Variation in the rainfall was found to be higher in the Gujarat state (28.78\%) and lower in Kerala (14.03\%). Area under primary forests declined in Kerala during 1940-1970, but the area under agroforestry/perennial crops (coconut, areca, and rubber) increased many fold during 1955-2000 [39], possibly contributing to the maintenance of ecological balance. 
Cropping intensity measures the degree of land use for cultivation in a particular year; it was found highest in Kerala (124.5\%). The higher amount of rainfall encourages multipurpose perennial crops and agroforestry in the region contributing to higher cropping intensity in Kerala [38]. Exploitation of rice fallows for cultivation of vegetables, pulses, and tuber crops during rabi season and summer season is also leading to higher cropping intensity. Cropping intensity is an important indicator of agricultural sustainability in the context of ecological security. In the process of increasing agricultural production, more and more area is being brought under cultivation, and farmers are growing more than one crop in the same field using modern inputs.

Intensive cropping has given rise to many problems such as soil infertility, water logging, and alkalinity and salinity of soil. Cropping intensity may, therefore, be taken as one of the determinants of ecological insecurity. Due to development of irrigation facilities under the arid climate of Gujarat, the net irrigated area (44.6\%) was found higher than other states. Irrigation stabilizes agricultural production and reduces the risk of crop failure with an increase in yield and food security. It would also provide a better prospect in terms of rural employment. The availability of groundwater is highest in Gujarat due to a higher number of irrigation projects with increased net irrigate area and it is lowest in Goa. Because of the ingression of seawater, most of the coastal area in Gujarat is submerged, which led to further land degradation (986,500 ha). The desert and arid climatic condition of Gujarat makes it excessively reliant on groundwater resources, which led to the highest groundwater stress $(56.85 \%)$ among the west coastal states. Reports by Jain, 2009 and Gupte and Patel, 2009 [40,41] support the high degree of over-exploitation of groundwater aquifers of Gujarat during the period 1984-2007.

They further reported that in Gujrat there were 26 over-exploited, 7 critical, 21 semi-critical, and 155 safe aquifers out of 223 aquifers. The replenishment/restoration of these highly stressed aquifers for economic development needs to be addressed through scientific interventions and suitable policy from the government sector. Indicators were useful to identify three ecologically insecure provinces among the 34 provinces of China. The provinces identified also recorded low agricultural production requiring attention to soil, land, and water management interventions [14].

\subsection{Economic Efficiency Index}

The economic efficiency of any state is very important as it is directly contributing to the GDP of the state. Gujarat has the highest net sown area as well as the highest net irrigation area compared to any other state. This shows the development of more irrigation projects led to increased net sown area. Net sown area was the second most important among the agroecosystem specific ecological indicators identified by Rao et al. (2019) [42]. Food grain yield of Goa is highest among the states on the west coast of India. Coastal districts of Karnataka are consuming more fertilizers than any other state on the west coast of India. This implies intensive cultivation of field and horticultural crops in this area. A soil-test-based recommendation of fertilizer is essential to increase agricultural productivity and sustainability; this in turn helps to meet the nutrition requirement of crops, improves soil fertility, and helps in rationalizing the cost incurred by the farmers on fertilizers.

Land productivity and labor availability are the most important considerations for substantial agricultural production. Gujarat has the highest land productivity as well as labor productivity compared to all coastal states in the western region. The higher land productivity in Gujarat might be due to higher irrigated areas, better availability of quality seeds, cooperative farming, and mechanization [17]. While the overall coastal region of Gujarat recorded high land productivity, nevertheless, the current study identifies potential areas for further development such as Kachchh District with a low SLSI value. Among all coastal districts, Uttara Kannada was found to be highest in ESI ranking in the current study but was poor in EEI and SEI. All three coastal districts of Karnataka were found to be ecologically sound but economically weak, which is analogous to an earlier study [10]. 


\subsection{Social Equity Index}

Generally, social equity throws light on the overall development of a society or community, which is of the foremost importance for any developing country. Food grain availability in Kerala is highest among the west coast states of India as in this region cropping intensity was found to be higher due to the adoption of a diversified cropping system. Swaminathan and Bhavani (2013) [43] opined that self-sustained food grain production forms the basis of livelihood security in rural India where people depend on agriculture. Milk production is highest in Gujarat compared to any other state mainly because of the higher livestock density (Table 2) and well-organized dairy industry, coupled with more farmers' cooperatives and increased incentives from the government which led to the adoption of improved dairy practices in Gujarat. Garai et al. (2019) [36] reported that the district with a higher number of crossbred cattle led to higher milk production and availability. Chand et al. (2015) [44] opined that smallholder dairy farming is an important enterprise in ensuring livelihood and nutritional security to the agrarian community in India.

Rural female literacy is of great importance as women are associated with agricultural and social activities. The higher literacy rate will definitely help to improve the economic and social status of any region or country. Coastal Karnataka has secured the highest literacy rate for women $(77.78 \%)$ compared to the rest of the states. All the coastal districts in the west coast states of India are almost fully electrified and well provided with road facilities. Due to a shortage of electricity supply, farmers were bound to use fuel-operated pumps in the Samastipur district of Bihar, India leading to increased pollution [8]. Hence, it is necessary to ensure pure air in rural areas by providing the electricity supply or alternate energy resources. It reduces transport costs with possible positive results on the prices realized by farmers. By improving communication, roads can increase the options available to rural producers, connecting them with larger national, regional, and even international markets.

The infant mortality rate indirectly throws light on the nourishment status of the women during pregnancy. Infant mortality is one of the major indicators used to identify the high-priority districts for health-related policy interventions $[45,46]$. Among the west coastal states, Kerala has the lowest infant mortality rate. This is mainly due to better nutrition of pregnant women and more primary healthcare centers and childcare programs from the government to pregnant women. All these indicators contribute to a high social equity index score in Kerala (Table 4) followed by Gujarat and Karnataka. Saleth (1993) [4] opined that west coast regions (Kerala, Karnataka, and Gujarat) were more socially equitable among the 80 samples across all the agro-climatic zones of India. The social equity ratio can be improved by improving education, health care, and hygiene facilities with strengthening rural infrastructure by road connectivity, along with electrification [16].

\subsection{Sustainable Livelihood Security Index (SLSI)}

The analyzed districts of west coast India were also characterized by extensive differences in terms of the SLSI. The indicators such as forest cover, net sown area, milk availability, groundwater availability, land productivity, food grain availability, rural road connectivity, villages electrified, and land degradation were found important indicators affecting the SLSI. This represents the overall importance of ecological, economic, and social indicators for a holistic development of the Indian west region. The PCA technique was used [47] to shortlist the indicators to develop a composite index for measuring development in the Philippines. As more forest cover plays an important role in the conservation of biodiversity and sustenance of water bodies, it thereby enhances the livelihood of the people. It also provides different ecosystem services both in terms of economic and ecological functions. Improved forest cover improves the groundwater availability to the inhabitants. Higher groundwater availability signifies that groundwater is available for future use but careful management is required to maintain the optimum level with adequate soil and water conservation measures. Similarly, higher food grain availability and milk yield indicate high land and animal productivity, which may be due to R \& D support, and technological advancement. The augmented crop and livestock production enhance food and nutritional security of a region. The rural road connectivity and villages electrified connects the 
rural population to nearby cities, improves education levels, and establishes better communication, and farmers can have easy access to electricity for agricultural purposes and access the local market for marketing farm produce. The other indicators such as higher net sown area increase cropping intensity and provide the opportunity for crop diversification, thereby improving overall agricultural production in that particular region.

The results indicated the coastal region of the Kerala state is the most developed region in the west coast of India. The highest SLSI value of Kerala state is mainly due to higher ESI, EEI, and SEI rankings for all the coastal districts of the state. The higher SLSI ranking of coastal Kerala implied that the state has the best ecological and socio-economic conditions for sustainable development. In an earlier study, agricultural sustainability in different states of India measured over a ten-year gap indicated that the sustainable agricultural progress in the state of Kerala has made it move from sixth to the second position from 2001 to 2011 [48]. Our findings are analogous to this study on agricultural suitability. Similarly, the high SLSI ranking of coastal Kerala can be attributed to the policies for socio-economic development implemented in the state, which were recognized as a model to emulate for evolving sustainable development in any region [49,50]. Likewise, Malaysia has evolved mechanisms for sustainable development and is able to implement policies and development programs successfully to increase income and eradicate poverty in the country. This has led to increase in household income and it was found to be correlated with an increased sustainable livelihood index in Malaysia [51].

In the same way, the coastal states of western India having the least desirable conditions for sustainable development with lower SLSI values were Goa and coastal Maharashtra. Earlier researchers also highlighted the importance of an SLSI in making policy decisions and to assess the performance of a region. In our study, the coastal districts such as Ratnagiri, Sindhudurg, Jamnagar, Junagadh, and Kachchh were found less sustainable. This may be attributed to natural geographical conditions in the west coast of India. The Jamnagar, Junagadh, and Kachchh districts of Gujarat fall under the category of arid regions with low cropping intensity and successive droughts. These factors negatively affect agricultural production and livestock production in that particular region. This has led to low socio-economic development of the region, consequently, less sustainable development. On an ecological front, the groundwater exploitation and salinity forms are another most striking cause of less sustainability of the region. Even though some districts like Ratnagiri and Sindhudurg were ecologically sustainable but economically unsustainable (Table 5), it may be due to other factors such as lower cropping intensity, net irrigated area, and land degradation.

Gupta (1970) [52] characterized Ratnagiri and Sindhudurg districts of Maharashtra as problematic areas of India due to the outmigration of people for livelihood, geographical disadvantage like rough terrain, and intra-regional developmental disparity. Therefore, investments in agriculture, rural development, and generation of employment are essential in these neglected regions. Talukder et al. (2015) [13] evaluated the sustainability of agricultural systems in coastal Bangladesh by developing a comprehensive suite of indicators. They suggested drafting appropriate policies for improving the agricultural sustainability of the particular regions. Similarly, decentralized planning and policies can be drafted for the west coast region of India for improving the less sustainable regions or districts based on the composite index (SLSI). Fumagalli et al. (2011) [11] worked on the agricultural sustainability of cropping systems and highlighted critical environmental issues, which will be helpful for the people to improve management in cropping systems. In the case of the west coast region in districts with very low ecological indicators (Kutch, Jamnagar, and Amreli), forest development programs such as Agroforestry and social forestry with community participation can be promoted and environmental quality can be improved for better living. Sharma and Shardendu (2011) [12] estimated farm-level agricultural sustainability in rural eastern India over a period of 60 years and inferred that the agricultural practices of the region have maintained sustainability so far and further scope exists for improvement in several broad areas. You and Zhang (2017) [18] worked on sustainable livelihood and rural sustainability in China and they concluded that the SLSI and its components vary between 
provincial regions of China. However, the current study indicates the regional disparities even within coastal states of western India for finer adjustments in state-level policy interventions [10,53,54].

\section{Conclusions and Recommendations for the Indian West Coast Region in the Context of Sustainable Development}

Computation of an SLSI significantly guides planning and development activities through delineating districts with varying levels of sustainable development. The study highlights the significance of non-linear scoring function over linear scoring function in reflecting the system functions more accurately. The indicators such as forest cover, net sown area, milk availability, groundwater availability, land productivity, food grain availability, rural road connectivity, villages electrified, and land degradation were found to be important indicators affecting the sustainable livelihood security index. In the non-linear weighted score, Kerala is the leading state compared to other states as all parameters except net sown area scored well. In the case of Gujarat, net sown area, milk availability, available groundwater, and labor productivity has secured the maximum score over the rest of the others. The current study adds to the existing knowledge of indicators of the overall sustainability of state-level studies. The focus on a district as the unit for the analysis of sustainability and positioning of them using linear and nonlinear weighted approaches reveals the degree of sustainability. This brings more insights about the ecological, economic, and social dimensions and aids in decentralized planning. The study identifies some districts (Jamnagar, Junagadh, and Kachchh of Gujarat and Ratnagiri and Sindhudurg of Maharashtra) as the highest priority districts of the Indian west coast for development and planning. The policies in promoting agricultural activities like integrated farming systems, organic farming, micro-irrigation, and agro-ecotourism activities will boost the supply of raw material to small and large-scale industries, spur employment generation, and provide regular income to farming families. Rural electrification, road connectivity, expansion of irrigation projects, and watershed development will boost the sustainability of these neglected districts. Therefore, the present study advocates policy interventions in economic and ecological sustainability at the district level to achieve sustainable development within the stipulated period.

Author Contributions: Conceptualization, V.R.K., V.P., V.A., B.D., H.O.E., D.D.R., K.S.S., D.O.E.-A., and E.A.M.; Data curation, V.R.K. and A.P.; Formal analysis, V.R.K., V.A., B.D., D.D.R., D.O.E.-A., and E.A.M.; Funding acquisition, V.P., V.A., D.D.R., and M.A.E.-S.; Investigation, H.O.E. and A.P.; Methodology, K.S.S. and D.O.E.-A.; Project administration, V.R.K., V.A., D.D.R., and E.A.M.; Resources, V.P.; Software, A.P.; Validation, M.A.E.-S.; Visualization, A.P.; Writing-original draft, B.D., H.O.E., K.S.S., and M.A.E.-S.; Writing-review and editing, V.P., B.D., H.O.E., K.S.S., D.O.E.-A., E.A.M., and M.A.E.-S. All authors have read and agreed to the published version of the manuscript.

Funding: The authors extend their appreciation to the Researchers Supporting Project Number (RSP-2020/182), King Saud University, Riyadh, Saudi Arabia. This research project was funded by ICAR-Central Coastal Agricultural Research Institute, Goa, India.

Acknowledgments: The authors extend their appreciation to the Researchers Supporting Project Number (RSP-2020/182), King Saud University, Riyadh, Saudi Arabia. The authors express gratitude to the authors of various government reports, which have been generously used in the preparation of this paper and ICAR-Central Coastal Agricultural Research Institute, Goa and ICAR-Central Tobacco Research Institute, Rajahmundry for providing necessary facilities and support.

Conflicts of Interest: The authors declare no conflict of interest.

\section{Abbreviations}

$\begin{array}{ll}\text { SLSI } & \text { Sustainable Livelihood Security Index } \\ \text { SDGs } & \text { Sustainable Development Goals } \\ \text { PCA } & \text { Principal Component Analysis } \\ \text { MDS } & \text { Minimum Data Set } \\ \text { ESI } & \text { Ecological Security Index } \\ \text { EEI } & \text { Economic Efficiency Index } \\ \text { SEI } & \text { Social Equity Index }\end{array}$




\section{References}

1. WCED. World Commission on Environment and Development: Our Common Future; Oxford University Press: Oxford, UK, 1987. Available online: https://idl-bnc-idrc.dspacedirect.org/bitstream/handle/10625/152/ WCED_v17_doc149.pdf? (accessed on 14 March 2020).

2. Swaminathan, M.S. From Stockholm to Rio de Janeiro: The road to sustainable agriculture. In Monograph; MS Swaminathan Research Foundation: Chennai, India, 1991.

3. Sajjad, H.; Nasreen, I. Assessing farm-level agricultural sustainability using site-specific indicators and sustainable livelihood security index: Evidence from Vaishali district, India. Community Dev. 2016, 47, 602-619. [CrossRef]

4. Saleth, R.M. Agricultural sustainability status of the agro- climatic sub-zones of India: Empirical illustration of an indexing approach. Indian J. Agric. Econ. 1993, 48, 543-550.

5. Böhringer, C.; Jochem, P.E.P. Measuring the immeasurable-A survey of sustainability indices. Ecol. Econ. 2007, 63, 1-8. [CrossRef]

6. Stimson, R.; Stough, R.; Roberts, B. Regional Economic Development. In Analysis and Planning Strategy; Springer: Heidelberg, Germany, 2006; ISBN 978-3540348290.

7. Bartniczak, B.; Raszkowski, A. Sustainable development in the Russian Federation-Indicator-based approach. Probl. Ekorozw. Probl. Sustain. Dev. 2017, 12, 133-142.

8. Alińska, A.; Filipiak, B.; Kosztowniak, A. The Importance of the Public Sector in Sustainable Development in Poland. Sustainability 2018, 10, 3278. [CrossRef]

9. Pawłowski, A. How many dimensions does sustainable development have? Sustain. Dev. 2008, 16, 81-90. [CrossRef]

10. Kumar, S.; Raizada, A.; Biswas, H. Prioritising development planning in the Indian semi-arid Deccan using sustainable livelihood security index approach. Int. J. Sustain. Dev. World Ecol. 2014, 21, 332-345. [CrossRef]

11. Fumagalli, M.; Acutis, M.; Mazzetto, F.; Vidotto, F.; Sali, G.; Bechini, L. An analysis of agricultural sustainability of cropping systems in arable and dairy farms in an intensively cultivated plain. Eur. J. Agron. 2011, 34, 71-82. [CrossRef]

12. Sharma, D.; Shardendu, S. Assessing farm-level agricultural sustainability over a 60-year period in rural eastern India. Environmentalist 2011, 31, 325-337. [CrossRef]

13. Talukder, B.; Saifuzzaman, M.; van Loon, G.W. Sustainability of agricultural systems in the coastal zone of Bangladesh. Renew. Agric. Food Syst. 2015, 31, 148-165. [CrossRef]

14. You, H.; Zhang, X. Sustainable livelihoods and rural sustainability in China: Ecologically secure, economically efficient or socially equitable? Resour. Conserv. Recycl. 2016, 120, 1-13. [CrossRef]

15. Bhandari, B.S.; Grant, M. Analysis of livelihood security: A case study in the Kali-Khola watershed of Nepal. J. Environ. Manag. 2006, 85, 17-26. [CrossRef]

16. Hatai, L.D.; Sen, C. An Economic Analysis of Agricultural Sustainability in Orissa. Agric. Econ. Res. Rev. 2008, 21, 273-282.

17. Singh, P.K.; Hiremath, B.N. Sustainable livelihood security index in a developing country: A tool for development planning. Ecol. Indic. 2010, 10, 442-451. [CrossRef]

18. Nambiar, K.K.; Gupta, A.; Fu, Q.; Li, S. Biophysical, chemical and socio-economic indicators for assessing agricultural sustainability in the Chinese coastal zone. Agric. Ecosyst. Environ. 2001, 87, 209-214. [CrossRef]

19. Farnham, A.; Utzinger, J.; Kulinkina, A.V.; Winkler, M.S. Using district health information to monitor sustainable development. Bull. World Health Organ. 2020, 98, 69-71. [CrossRef]

20. DESA (Department of Economic and Social Affairs), Sustainable Development, United Nations. 2020. Available online: http://www.un.org/sustainabledevelopment/news/communications-material/ (accessed on 10 June 2020).

21. Emas, R. The Concept of Sustainable Development: Definition and Defining Principles. Brief GSDR 2015, 1-3. Available online: https://sustainabledevelopment.un.org/content/documents/5839GSDR\%202015_SD_ concept_definiton_rev.pdf (accessed on 15 January 2020).

22. Syaifudin, N.; Wu, Y. Sustainable Development in Indonesian Regions: Towards an Assessment. In Sustainability Perspectives: Science, Policy and Practice; Springer: Cham, Switzerland, 2020; pp. 41-61. [CrossRef]

23. Hickel, J. The sustainable development index: Measuring the ecological efficiency of human development in the anthropocene. Ecol. Econ. 2020, 167, 106331. [CrossRef] 
24. Rajasree, B.R.; Deo, M.C. Assessment of Coastal Vulnerability Considering the Future Climate: A Case Study along the Central West Coast of India. J. Waterw. Port Coastal Ocean Eng. 2020, 146, 05019005. [CrossRef]

25. Ahsan, M.N.; Warner, J. The socioeconomic vulnerability index: A pragmatic approach for assessing climate change led risks-A case study in the South-Western coastal Bangladesh. Int. J. Disaster Risk Reduct. 2014, 8, 32-49. [CrossRef]

26. Tölgyesi, C.; Bátori, Z.; Erdős, L. Using statistical tests on relative ecological indicators to compare vegetation units-Different approaches and weighting methods. Ecol. Indic. 2014, 36, 441-446. [CrossRef]

27. Forest Survey of India, India State of Forest Report 2013; Forest Survey of India, Ministry of Environment and Forests, Government of India: Dehradun, India, 2013.

28. Population Census Reports; Office of Register General and Census Commissioner, Ministry of Home Affair Government of India: New Delhi, India, 2011.

29. Livestock Census Report; Department of Animal Husbandry, Dairying and Fisheries, Ministry of Agriculture, Government of India: New Delhi, India, 2012.

30. Maji, A.K.; Reddy, G.P.O.; Sarkar, D. Degraded and wastelands of India: Status and spatial distribution. Indian Counc. Agric. Res. New Delhi 2010. Available online: http://www.icar.org.in/files/Degraded-andWastelands.pdf (accessed on 15 February 2017).

31. Indian Meteorological Department; Ministry of Earth Sciences, Government of India: Pune, India, 2016.

32. CGWB \& MoWR, Dynamics of Groundwater Resources of India; Central Ground Water Board, Ministry of Water Resources, Government of India: New Delhi, India, 2011.

33. DES Reports, Statistical Reports of Directorate of Economics and Statistics; Government of Goa, Panaji: Goa State, India; Government of Karnataka, Bangalore: Karnataka, India; Government of Kerala, Trivandrum: Kerala, India; Government of Maharashtra, Mumbai: Maharashtra, India; Government of Gujrat, Gandhinagar: Gujrat, India, 2014.

34. District Census Hand Book; Office of Registrar General and Census Commissioner of India, Ministry of Home Affair, Government of India: New Delhi, India, 2011.

35. Brejda, J.J.; Karlen, D.L.; Smith, J.L.; Allan, D.L. Identification of Regional Soil Quality Factors and Indicators: II. Northern Mississippi Loess Hills and Palouse Prairie. Soil Sci. Soc. Am. J. 2000, 64, 2125-2135. [CrossRef]

36. Garai, S.; Ghosh, M.K.; Maiti, S.; Garai, S.; Meena, B.S.; Dutta, T.K.; Kadian, K.S. Development and application of dairy-based sustainable livelihood security index in the districts of West Bengal, India: A tool for dairy development planning. J. Rural Stud. 2019, 17, 1-9. [CrossRef]

37. Kale, R.B.; Ponnusamy, K.; Chakravarty, A.K.; Sendhil, R.; Mohammad, A. Assessing resource and infrastructure disparities to strengthen Indian dairy sector. Indian J. Anim. Sci. 2016, 86, 720-725.

38. Watson, R.T.; Noble, I.R.; Bolin, B.; Ravindranath, N.H.; Verardo, D.J.; Dokken, D.J. Land Use, Land-Use Change and Forestry: A Special Report of the Intergovernmental Panel on Climate Change; Cambridge University Press: Cambridge, UK, 2000.

39. Kumar, B.M. Land use in Kerala: Changing scenarios and shifting paradigms. J. Trop. Agric. 2006, 43, 1-12.

40. Jain, R.C. Trends and sustainability of groundwater in highly stressed aquifers of Gujarat, India. In Trends and Sustainability of Groundwater in Highly Stressed Aquifers. Proceedings of Symposium HS. 2 at the Joint Convention of the International Association of Hydrological Sciences (IAHS) and the International Association of Hydrogeologists (IAH) Held I; IAHS Press: Wallingford, UK, 2009; pp. 36-46.

41. Gupte, P.R.; Patel, J.R. Status of groundwater resources and management, Gujarat state, India strategies for sustainable management. In Proceedings of the III World Aqua Congress, New Delhi, India, 2 December 2009; pp. 6-14.

42. Rao, C.S.; Kareemulla, K.; Krishnan, P.; Murthy, G.R.K.; Ramesh, P.; Ananthan, P.S.; Joshi, P.K. Agro-ecosystem based sustainability indicators for climate resilient agriculture in India: A conceptual framework. Ecol. Indic. 2019, 105, 621-633.

43. Swaminathan, M.S.; Bhavani, R.V. Food production and availability-Essential prerequisites for sustainable food security. Indian J. Med. Res. 2013, 138, 383. [PubMed]

44. Chand, P.; Sirohi, S.; Sirohi, S.K. Development and application of an integrated sustainability index for smallholder dairy farms in Rajasthan, India. Ecol. Indic. 2015, 56, 23-30. [CrossRef]

45. De Freitas, D.S.; de Oliveira, T.E.; de Oliveira, J.M. Sustainability in the Brazilian pampa biome: A composite index to integrate beef production, social equity, and ecosystem conservation. Ecol. Indic. 2019, 98, 317-326. [CrossRef] 
46. Taneja, G.; Sridhar, V.S.-R.; Mohanty, J.S.; Joshi, A.; Bhushan, P.; Jain, M.; Gupta, S.; Khera, A.; Kumar, R.; Gera, R. India is RMNCH+ A Strategy: Approach, learnings and limitations. BMJ Glob. Health 2019, 4, e001162. [CrossRef] [PubMed]

47. Barrios, E.; Komoto, K. Some approaches to the construction of a sustainable development index for the Philippines. Int. J. Sustain. Dev. World Ecol. 2006, 13, 277-288. [CrossRef]

48. Kareemulla, K.; Venkattakumar, R.; Samuel, M.P. An analysis on agricultural sustainability in India. Curr. Sci. 2017, 112, 258-266. [CrossRef]

49. Roboredo, D.; Bergamasco, S.M.P.P.; Bleich, M.E. Aggregate index of social-environmental sustainability to evaluate the social-environmental quality in a watershed in the Southern Amazon. Ecol. Indic. 2016, 63, 337-345. [CrossRef]

50. Véron, R. The "new" Kerala model: Lessons for sustainable development. World Dev. 2001, 29, 601-617. [CrossRef]

51. Kamarrudin, R.; Samsudin, S. The sustainable livelihoods index: A tool to assess the ability and preparedness of the rural poor in receiving entrepreneurial project. J. Soc. Econ. Res. 2014, 1, 108-117.

52. Gupta, P.S. Population and Resource Development in India. Geography and a Crowding World: A Symposium on Population Pressures upon Physical and Social Resources in the Developing Lands; Zelinsky, W., Ed.; Oxford University Press: New York, NY, USA, 1970; pp. 424-441.

53. Liu, L. A sustainability index with attention to environmental justice for eco-city classification and assessment. Ecol. Indic. 2018, 85, 904-914. [CrossRef]

54. Rai, A.; Sharma, S.D.; Sahoo, P.M.; Malhotra, P.K. Development of livelihood index for different agro-climatic zones of India. Agric. Econ. Res. Rev. 2008, 21, 173-182.

Publisher's Note: MDPI stays neutral with regard to jurisdictional claims in published maps and institutional affiliations. 